\title{
Oznaczenia składu grupowego olejów bazowych
}

\begin{abstract}
W artykule przedstawiono wyniki pracy poświęconej korelacji wyników oznaczania składu węglowodorowego wybranych próbek olejów bazowych wykonanego metodami znormalizowanymi, według PN-72/C-04025, ASTM D 2007-11 oraz procedury opisanej w Załączniku A do działu 27 Not wyjaśniających do Nomenklatury Scalonej Unii Europejskiej. Wydzielone frakcje węglowodorowe poddano analizie technikami chromatografii gazowej oraz spektrometrii w podczerwieni (FT-IR) w celu oszacowania różnic ich składu. Przedstawiono także wpływ przykładowego komponentu syntetycznego - PAO-4 na przebieg oznaczania składu węglowodorowego.
\end{abstract}

Słowa kluczowe: skład węglowodorowy, oleje bazowe, polialfaolefiny.

\section{Determination of the hydrocarbons group in base oils}

The article presents the results of work on the correlation of the results determining the hydrocarbon composition of selected samples of base oils done by methods PN-72/C-04025, Appendix A to Chapter 27 of the Explanatory Notes of the Combined Nomenclature and by ASTM D 2007-11. The separated hydrocarbon fractions were analyzed by gas chromatography and infrared spectrometry (FT-IR) techniques to estimate the differences in their composition. The influence of an exemplary synthetic component - PAO-4 on the course of hydrocarbon composition determination is also presented.

Key words: the hydrocarbon base oils, polyalphaolefins.

\section{Wstęp}

Oznaczanie składu węglowodorowego produktów naftowych to ważny element oceny ich jakości. Skład chemiczny olejowych frakcji z destylacji ropy naftowej jest bardzo złożony [9]. Oprócz podstawowych składników, jakie stanowią grupy węglowodorów o charakterze nasyconym, takich jak: parafiny o łańcuchu normalnym i rozgałęzionym, cykloparafiny (nafteny) i ich homologi (związki alicykliczne), należą do niego nadające charakter frakcjom naftowym węglowodory aromatyczne, podobnie jak nafteny zawierające podstawniki alkilowe. Węglowodory nienasycone praktycznie we frakcjach olejowych nie występują, a ich pojawienie się świadczy o rozpadzie termicznym składników ropy naftowej podczas procesów przeróbki. W cięższych frakcjach obecne mogą być również skondensowane struktury wielopierścieniowe, w tym niepożądane wielopierścieniowe węglowodory aromatyczne oraz związki zawierające heteroatomy, które ze względu na niekorzystny wpływ na jakość olejów są usuwane podczas przerobu frakcji.

Zastosowanie do produkcji olejów bazowych różnych procesów technologicznych ma istotny wpływ na ich skład oraz budowę chemiczną. Równolegle z rozwojem analityki ropy nafto- wej w INiG - PIB sprawdzano możliwości oznaczenia składów strukturalno-grupowych z wykorzystaniem znormalizowanych technik chromatografii elucyjnej [6]. Celem tego rodzaju prac było porównanie technik oceny składu grupowego destylatów próżniowych i otrzymywanych z nich olejów bazowych, stanowiących surowiec do uzyskiwania współczesnych olejów smarowych, w tym wykorzystujących komponenty syntetyczne (PAO).

Instytut uczestniczył w opracowaniu Polskiej Normy PN-72/C-04025 Oznaczanie składu grupowego weglowodorów metoda chromatografii elucyjnej [16]. Przedmiotem tej normy jest oznaczanie składu grupowego węglowodorów w produktach naftowych o temperaturze początku wrzenia powyżej $180^{\circ} \mathrm{C}$ wytworzonych w procesie zachowawczej i destrukcyjnej przeróbki ropy naftowej. Procedura ta jest stosowana przede wszystkim do oznaczania składu grupowego frakcji olejów bazowych przeznaczonych do produkcji olejów silnikowych oraz do ekstraktów otrzymywanych z selektywnej rafinacji olejów. Norma oferuje dwie procedury analityczne. Metoda A pozwala na oznaczenie zawartości węglowodorów nasyconych (mieszanina homologów węglowodorów parafinowych i naftenowych), trzech 
grup węglowodorów aromatycznych oraz substancji polarnych określanych jako, żywwice”. Metoda B (skrócona), w której nie prowadzi się rozdziału węglowodorów aromatycznych na grupy, zyskując na czasie oznaczania, umożliwia szybką ocenę zawartości komponentów aromatycznych i żywic.

W pracy wykorzystano również szeroko stosowaną znormalizowaną metodę ASTM D 2007-11 [11], pozwalającą na chromatograficzne oznaczenie zawartości węglowodorów nasyconych (parafinowych), aromatycznych i związków polarnych we frakcjach i produktach naftowych o temperaturze początku wrzenia powyżej $260^{\circ} \mathrm{C}$.

Kolejną metodą chromatograficzną stosowaną w niniejszej pracy jest procedura opisana w Załączniku A do działu 27 Not wyjaśniających do Nomenklatury Scalonej UE pt.: Metody oznaczania zawartości aromatycznych sktadników w produktach o końcowej temperaturze destylacji przekraczajacej $315^{\circ} \mathrm{C}$ [19]. Metoda ta polega na umieszczeniu próbki rozpuszczonej w n-pentanie w kolumnie chromatograficznej o określonych wymiarach, napełnionej żelem krzemionkowym, a następnie wymyciu n-pentanem substancji niepolarnych, uznawanych za składniki niearomatyczne. Oznaczenie tego parametru jest istotne dla potrzeb urzędów celnych.

W tablicy 1 zamieszczono krótką charakterystykę znormalizowanych metod wykorzystujących chromatografię cieczową.
Równolegle wraz z rozwojem analityki instrumentalnej powiększano warsztat analityczny, wdrażano i opracowywano nowe metody analityczne. Technika chromatografii gazowej umożliwiła szybką ocenę dystrybucji temperatur destylacji frakcji naftowych [3,15], a dzięki zastosowaniu techniki chromatografii gazowej z detektorem mas, opisanej w normie ASTM D 2425 [14], uzyskano informacje o wielu grupach związków obecnych w średnich i cięższych destylatach naftowych, takich jak: alkany, mono-, di-, tricykloparafiny, alkilobenzeny, indany, indeny, naftaleny, acenafteny, acenaftyleny i węglowodory trójpierścieniowe, w tym również pochodne fenantrenu i antracenu.

Jedną z technik rozdziału grupowego rop naftowych i pozostałości z destylacji jest technika SARA. Procedura ta [4] umożliwia ilościowy rozdział ropy naftowej na węglowodory nasycone (saturate), aromatyczne (aromatic), żywice (resin) i asfalteny (asphaltene). Osadzanie asfaltenów jest dobrze znanym problemem $[1,8]$ i generuje wzrost kosztów w przemyśle naftowym, niemniej ta procedura włączająca wytrącenie komponentów asfaltenowych z produktów naftowych została pominięta w dalszych rozważaniach ze względu na ich brak w olejach bazowych, zwłaszcza gdy rozdział frakcji uzyskanej po oddzieleniu asfaltenów jest prowadzony techniką chromatograficzną zgodną z procedurą stosowaną w Polskiej Normie [16].

Tablica 1. Zestawienie znormalizowanych metod oznaczania składu strukturalno-grupowego produktów naftowych technikami chromatograficznymi

\begin{tabular}{|c|c|c|c|}
\hline Norma & $\begin{array}{l}\text { Stosowane sorbenty/warunki } \\
\text { chromatograficzne }\end{array}$ & Stosowane eluenty & Uzyskany rozdział \\
\hline $\begin{array}{l}\text { ASTM D } 1319[10] \\
\text { PN-EN } 15553[18]\end{array}$ & żel krzemionkowy & propanol & $\begin{array}{l}\text { węglowodory: } \\
\text { - aromatyczne } \\
\text { - nasycone } \\
\text { - olefiny }\end{array}$ \\
\hline PN-EN 12916 [17] & $\begin{array}{l}\text { wysokosprawny chromatograf } \\
\text { cieczowy z polarną kolumną }\end{array}$ & heptan & $\begin{array}{l}\text { węglowodory aromatyczne: } \\
\text { - jedno-, dwu-, } \\
\text { - trój- i wielopierścieniowe }\end{array}$ \\
\hline PN-72/C-04025 [16] & $\begin{array}{l}\text { - żel krzemionkowy } \\
\text { - tlenek glinu }\end{array}$ & $\begin{array}{l}\text { - eter naftowy } \\
\text { - benzen } \\
\text { - etanol }\end{array}$ & $\begin{array}{l}\text { węglowodory: } \\
\text { - aromatyczne } \\
\text { - parafino-nafteny } \\
\text { - polarne }\end{array}$ \\
\hline ASTM D 2007 [11] & $\begin{array}{l}\text { - żel krzemionkowy } \\
\text { - attapulgit }\end{array}$ & $\begin{array}{l}\text { - n-pentan } \\
\text { - toluen } \\
\text { - aceton }\end{array}$ & $\begin{array}{l}\text { węglowodory: } \\
\text { - aromatyczne } \\
\text { - nasycone } \\
\text { - polarne }\end{array}$ \\
\hline ASTM D 4124 [13] & - tlenek glinu & $\begin{array}{l}\text { - n-heptan } \\
\text { - toluen } \\
\text { - metanol } \\
\text { - trichloroetylen }\end{array}$ & \\
\hline ASTM D 2549 [12] & $\begin{array}{l}\text { - żel krzemionkowy } \\
\text { - tlenek glinu }\end{array}$ & & $\begin{array}{l}\text { - składniki aromatyczne } \\
\text { - składniki niearomatyczne }\end{array}$ \\
\hline $\begin{array}{l}\text { Załącznik A [19] do działu } 27 \text { Not } \\
\text { wyjaśniających do Nomenklatury } \\
\text { Scalonej UE* }\end{array}$ & żel krzemionkowy & n-pentan & $\begin{array}{l}\text { - składniki niearomatyczne } \\
\text { - składniki aromatyczne }\end{array}$ \\
\hline
\end{tabular}

* Procedury wykorzystane w prowadzonych badaniach. 
W 2009 r. w Zakładzie Analiz INiG - PIB prowadzono pracę badawczą [5] mającą na celu sprawdzenie możliwości wykorzystania techniki GC/MS, opisanej w normie ASTM D 2425:04 [14], do badania składu strukturalno-grupowego podstawowych olejów smarowych [4]. Wykonane badania nie pozwoliły jednak na uzyskanie wiarygodnych wyników ilościowych przy wykorzystaniu tej techniki do badania olejów typu Solvent Neutral, nawet w przypadku olejów typu SN 100. Przyczyny tego można upatrywać przede wszystkim w różnych sposobach wprowadzania próbki do źródła jonów spektrometru (norma zalecała wprowadzanie bezpośrednie próbki, podczas gdy w pracy stosowano dostępny zestaw GC/MS) i wynika- jących z tego faktu różnic wartości współczynników przeliczeniowych. Niemniej tę technikę należy uznać za perspektywiczną, nadającą się do pótilościowej oceny struktur występujących w badanych frakcjach. W dalszych badaniach technikę GC/MS zastosowano przy charakterystyce składu średnich destylatów naftowych [7].

Ze względu na ważność wiedzy o składzie węglowodorowym wykorzystywanych w gospodarce olejów bazowych i związek tego składu z jakością uzyskiwanych z nich produktów - podjęto badania nad korelacją wyników oznaczań tego składu zalecanymi i często stosowanymi znormalizowanymi metodami analitycznymi.

\section{Materiał do badań}

Do badań wytypowano następujące próbki:

- olej bazowy 1 , grupy 1 według API - otrzymywany z zachowawczej przeróbki ropy naftowej, selektywnie rafinowany furfurolem, odparafinowany metodą rozpuszczalnikową, a następnie poddany rafinacji wodorem,

- olej bazowy 2 - również należący do olejów grupy pierwszej według API, otrzymywany z zachowawczej przeróbki ropy naftowej, selektywnie rafinowany furfurolem, odparafinowany metodą rozpuszczalnikową, a następnie poddany rafinacji wodorem,

- olej syntetyczny PAO-4 - produkt polimeryzacji 1-decenu i innych długołańcuchowych alfa-olefin $\mathrm{C}_{8}-\mathrm{C}_{12}$ [14] oraz dwie mieszaniny olejów bazowych i oleju syntetycznego:

- mieszaninę olejów: 1 z PAO-4 (przygotowano ją w sposób wagowy przez zmieszanie oleju $1(17,225$ g) z kom- ponentem PAO-4 (8,4890 g), uzyskując 33,0-proc. $(\mathrm{m} / \mathrm{m})$ roztwór PAO-4 w 1,

- mieszaninę olejów: 2 z PAO-4 (przygotowano ją w sposób wagowy przez zmieszanie oleju $2(19,7591 \mathrm{~g})$ z komponentem PAO-4 (8,7883 g), uzyskując 32,4-proc. $(\mathrm{m} / \mathrm{m})$ roztwór PAO-4 w 2.

Stosowana aparatura pomiarowa:

- szklane kolumny chromatograficzne - do przeprowadzania rozdziału technikami chromatografii elucyjnej (rysunek 1),

- chromatograf gazowy Agilent Technologies, model 7890B, umożliwiający wysokotemperaturowy rozdział chromatograficzny mieszanin produktów naftowych,

- spektrometr FT-IR firmy Bio-Rad, umożliwiający rejestrację widma w podczerwieni w zakresie 400-7000 $\mathrm{cm}^{-1}$,

- spektrometr UV-VIS U-2800 firmy Hitachi, umożliwiający pomiar absorbancji przy długości fali 200-1100 nm.

\section{Przeprowadzone badania}

Badanie wstepne próbek olejów syntetycznych typu PAO Analizy wykonano przy użyciu chromatografu gazowego Agilent 7890B wyposażonego w kolumnę kapilarną o wy-

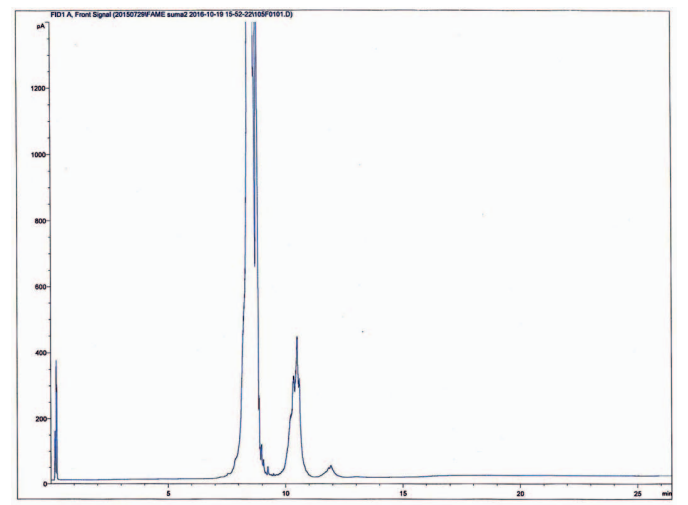

Rys. 1. Chromatogram PAO-4 wykonany techniką chromatografii gazowej miarach $15 \mathrm{~m} \times 0,32 \mathrm{~mm}$ z filmem fazy stacjonarnej metylopolisiloksan $95 \%$, fenylopolisiloksan $5 \%$, o grubości filmu $0,1 \mu \mathrm{m}$.

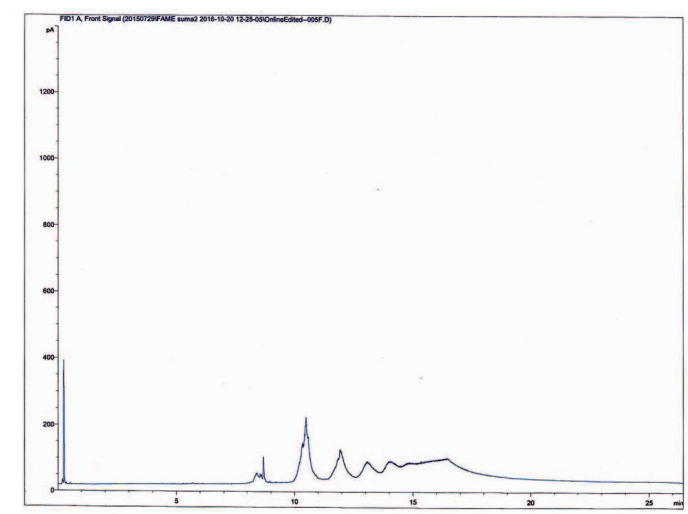

Rys. 2. Chromatogram PAO-40 wykonany techniką chromatografii gazowej 
Po przeanalizowaniu chromatogramów kolejno dla PAO-2, PAO-4, PAO-6, PAO-8, PAO-40, PAO-100 wybrano do dalszych analiz komponent PAO-4. Podyktowane to było charakterystycznym przebiegiem chromatogramu (charakterystyczne trzy maksima) (rysunek 1). Technika chromatografii gazowej nie dała zadowalającego rozdziału próbek polialfaolefin o dużych masach cząsteczkowych typu PAO-40 oraz PAO-100 (rysunek 2), co wiązało się prawdopodobnie ze zbyt wysokimi temperaturami destylacji obecnych w nich oligomerów, i z tego względu do dalszych badań mieszanin olejów bazowych wybrano olej PAO-4.

\section{Badania próbek olejów bazowych technikami chromatografii kolumnowej}

Analizę składu grupowego wybranych próbek przeprowadzono metodami według PN-72/C-04025, Załącznika A do działu 27 Not wyjaśniających do Nomenklatury Scalonej UE oraz według ASTM D 2007-11. Rozdziały chromatograficzne prowadzono, wykorzystując zestawy chromatograficzne pokazane na fotografii 1 .
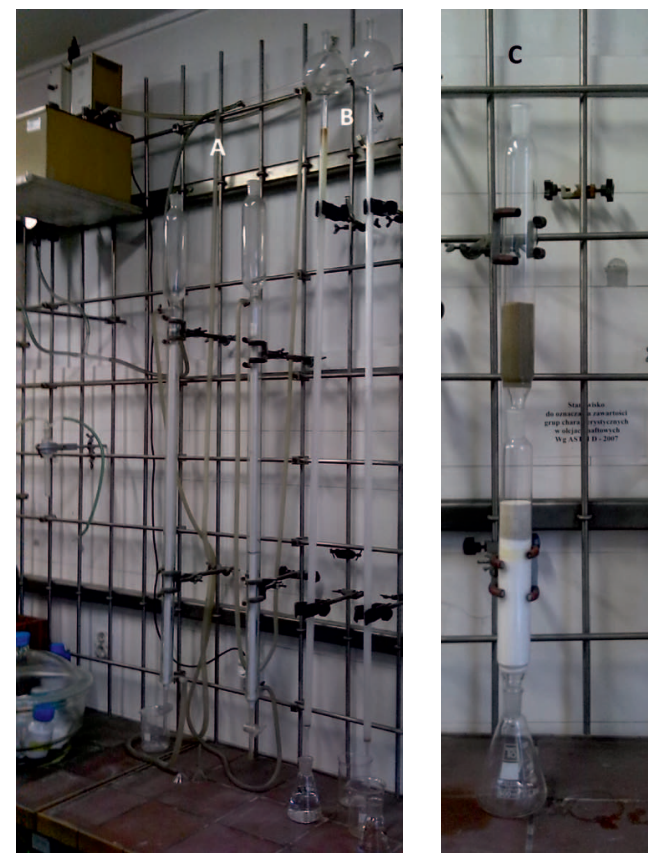

Fot. 1. Zestawy kolumn chromatograficznych stosowane przy rozdziałach próbek według: A - PN-72/C-04025 [3],

B - Załącznika A [5] oraz C - ASTM D 2007-11 [4]

\section{Analiza mineralnych olejów bazowych}

W pierwszej kolejności przeanalizowano handlowe oleje bazowe uzyskane z przerobu ropy naftowej (1 i 2). Zestawione wyniki potwierdziły korelację wszystkich trzech metod oznaczania zawartości składników niearomatycznych, tj. węglowodorów nasyconych i parafinowo-naftenowych.

Wyniki oznaczania składu grupowego próbki oleju $2 \mathrm{w}$ przypadku zastosowania rozdziału według Polskiej Normy oraz zawartości składników aromatycznych i nie-

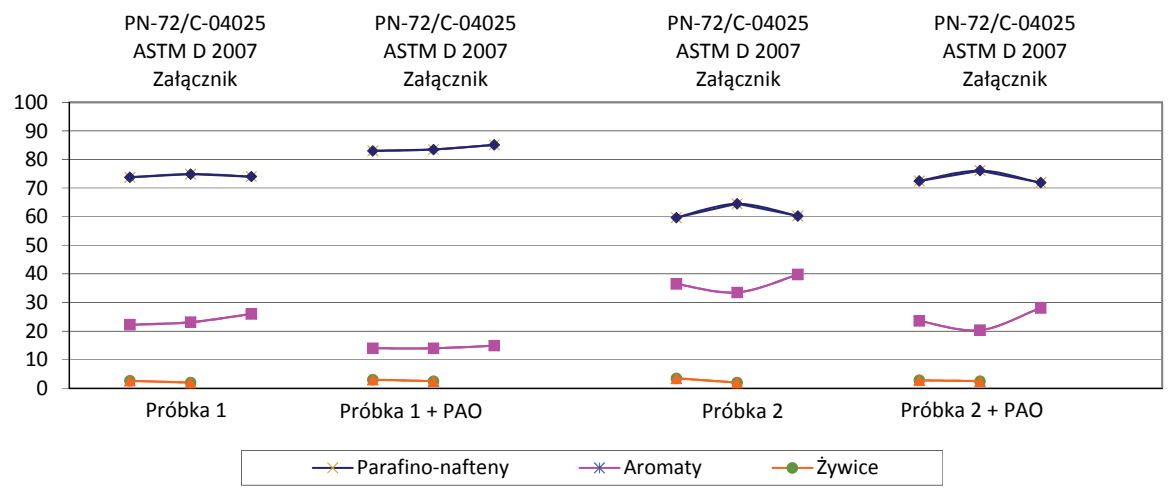

Rys. 3. Porównanie wyników analizy strukturalno-grupowej badanych mieszanin

Tablica 2. Zestawienie wyników rozdziałów próbek oleju bazowego 2 oraz 1 uzyskanych z wykorzystaniem trzech procedur badawczych

\begin{tabular}{|c|c|c|c|c|}
\hline \multirow{2}{*}{$\begin{array}{l}\text { Oznaczana cecha } \\
\text { Warunki badania }\end{array}$} & \multirow{2}{*}{ Jednostka } & \multicolumn{2}{|c|}{ Wynik pomiaru } & \multirow{2}{*}{ Metoda badania według } \\
\hline & & 2 & 1 & \\
\hline $\begin{array}{l}\text { Skład węglowodorowy: } \\
\text { - węglowodory parafinowo-naftenowe } \\
\text { - węglowodory aromatyczne } \\
\text { - żywice }\end{array}$ & $\%(m / m)$ & $\begin{array}{r}59,7 \\
36,5 \\
3,5 \\
\end{array}$ & $\begin{array}{r}73,8 \\
22,2 \\
2,6 \\
\end{array}$ & PN-72/C-04025 \\
\hline SUMA & $\%(m / m)$ & 99,7 & 98,6 & \\
\hline $\begin{array}{l}\text { Zawartość: } \\
\text { - składniki niearomatyczne } \\
\text { - składniki aromatyczne }\end{array}$ & $\%(m / m)$ & $\begin{array}{l}60,2 \\
39,8\end{array}$ & $\begin{array}{l}74,0 \\
26,0\end{array}$ & $\begin{array}{c}\text { Załącznik A do działu } 27 \text { Not } \\
\text { wyjaśniających do Nomenklatury } \\
\text { Scalonej UE }\end{array}$ \\
\hline $\begin{array}{l}\text { Zawartość: } \\
\text { - węglowodory nasycone } \\
\text { - węglowodory aromatyczne } \\
\text { - związki polarne }\end{array}$ & $\%(m / m)$ & $\begin{array}{r}64,5(4,0) \\
33,5(3,3) \\
2,0(1,3)\end{array}$ & $\begin{array}{r}74,9(4,0) \\
23,1(3,3) \\
2,0(1,3)\end{array}$ & ASTM D 2007:2011 \\
\hline
\end{tabular}


aromatycznych według załącznika A korelują ze sobą. Różnica między tymi wynikami wynosi $0,2 \%(\mathrm{~m} / \mathrm{m})$. Wynik oznaczania zawartości węglowodorów nasyconych według ASTM D 2007-11 jest wyższy od pozostałych, a różnica, wynosząca $4,8 \%(\mathrm{~m} / \mathrm{m})$, nieco przekracza wartość odtwarzalności meto- dy o najniższej precyzji, tj. odtwarzalności metody ASTM D 2007-11 $(R=4,0 \%(\mathrm{~m} / \mathrm{m}))$.

Zestawienie otrzymanych wyników analizy próbek oleju bazowego 1 oraz 2 przedstawiono graficznie na rysunku 3 i w tablicy 2 .

\section{Analiza mieszanin olejów bazowych grupy I z olejem grupy IV (PAO-4)}

Na bazie olejów 2 oraz 1 sporządzono mieszaniny zawierające około $33 \%(\mathrm{~m} / \mathrm{m})$ komponentu PAO-4. Chromatogram mieszaniny jednego z olejów został zaprezentowany na rysunku 4. Obliczone teoretyczne zawartości składników niearomatycznych w sporządzonych mieszaninach przedstawiono w tablicy 3 .

W sporządzonych próbkach, będących mieszaninami olejów I i IV grupy, oznaczono skład grupowy, a otrzymane wyniki przedstawiono w tablicy 4.

Po przeanalizowaniu wyników oznaczania składów grupowych sporządzonych mieszanin można stwierdzić, że dodanie syntetycznego komponentu, jakim jest PAO-4, nie wpływa w widoczny sposób na przebieg rozdziału i tym samym na jego wyniki. Podobnie w przypadku analizy mieszaniny na bazie oleju 1 uzyskane wyniki potwierdziły

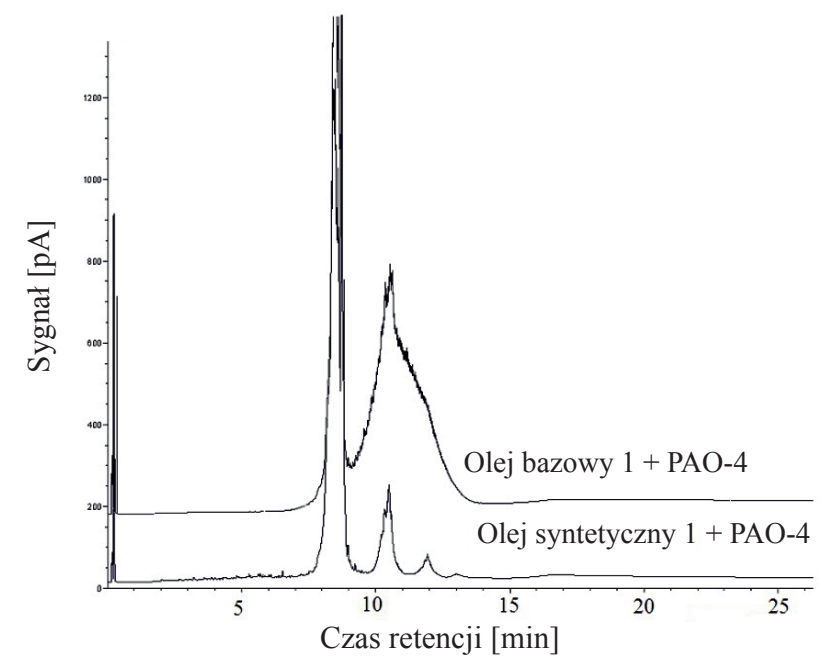

Rys. 4. Obraz chromatograficzny mieszanin oleju bazowego i syntetycznego

Tablica 3. Teoretyczna zawartość składników niearomatycznych w badanych mieszaninach olejów I i IV grupy

\begin{tabular}{|c|c|c|c|c|c|}
\hline \multirow{2}{*}{ Nazwa próbki } & \multicolumn{2}{|c|}{$\begin{array}{c}\text { Zawartość składników niearomatycznych } \\
\text { w oleju bazowym }[\%(\mathrm{~m} / \mathrm{m})]\end{array}$} & \multirow{2}{*}{ Nazwa próbki } & \multicolumn{2}{|c|}{$\begin{array}{l}\text { Obliczona zawartość składników } \\
\text { niearomatycznych po dodaniu PAO-4 }\end{array}$} \\
\hline & wg ASTM D 2007-11 & wg PN-72/C-04025 & & wg ASTM D 2007-11 & wg PN-72/C-04025 \\
\hline Olej bazowy 1 & 74,9 & 73,8 & $\begin{array}{c}\text { olej bazowy } 1+\text { PAO-4 } \\
33,0 \%(\mathrm{~m} / \mathrm{m})\end{array}$ & 83,2 & 82,4 \\
\hline Olej bazowy 2 & 64,5 & 59,7 & $\begin{array}{c}\text { olej bazowy } 2+\text { PAO-4 } \\
32,4 \%(\mathrm{~m} / \mathrm{m})\end{array}$ & 76,0 & 72,8 \\
\hline
\end{tabular}

Tablica 4. Zestawienie wyników rozdziałów próbki oleju bazowego 1 i 2 z około $33 \%(\mathrm{~m} / \mathrm{m})$ PAO-4 uzyskanych z wykorzystaniem trzech procedur badawczych

\begin{tabular}{|c|c|c|c|c|}
\hline \multirow{2}{*}{$\begin{array}{l}\text { Oznaczana cecha } \\
\text { Warunki badania }\end{array}$} & \multirow{2}{*}{ Jednostka } & \multicolumn{2}{|c|}{ Wynik pomiaru } & \multirow{2}{*}{ Metoda badania według } \\
\hline & & $2+\mathrm{PAO}$ & $1+\mathrm{PAO}$ & \\
\hline $\begin{array}{l}\text { Skład węglowodorowy: } \\
\text { - węglowodory parafinowo-naftenowe } \\
\text { - węglowodory aromatyczne } \\
\text { - żywice }\end{array}$ & $\%(m / m)$ & $\begin{array}{r}72,5 \\
23,6 \\
2,8\end{array}$ & $\begin{array}{r}83,0 \\
14,0 \\
3,0\end{array}$ & PN-72/C-04025 \\
\hline SUMA & $\%(m / m)$ & 98,9 & 100,0 & \\
\hline $\begin{array}{l}\text { Zawartość: } \\
\text { - składniki niearomatyczne } \\
\text { - składniki aromatyczne }\end{array}$ & $\%(m / m)$ & $\begin{array}{l}71,9 \\
28,1\end{array}$ & $\begin{array}{l}85,1 \\
14,9\end{array}$ & $\begin{array}{c}\text { Załącznik A do działu } 27 \text { Not } \\
\text { wyjaśniających do Nomenklatury } \\
\text { Scalonej UE }\end{array}$ \\
\hline $\begin{array}{l}\text { Zawartość: } \\
\text { - węglowodory nasycone } \\
\text { - węglowodory aromatyczne } \\
\text { - związki polarne }\end{array}$ & $\%(m / m)$ & $\begin{array}{r}76,1(4,0) \\
20,3(4,0) \\
2,5(4,0)\end{array}$ & $\begin{array}{r}83,5(4,0) \\
14,0(3,3) \\
2,5(1,3)\end{array}$ & ASTM D 2007-11 \\
\hline
\end{tabular}


Tablica 5. Zestawienie wyników obliczonych i oznaczonych zawartości składników niearomatycznych

\begin{tabular}{|c|c|c|c|c|}
\hline \multirow{2}{*}{ Nazwa próbki } & $\begin{array}{r}\text { Obliczona zawartość składników niearomatycznych } \\
\text { w mieszaninach z PAO-4 }\end{array}$ & $\begin{array}{r}\text { Oznaczona zawartość składników niearomatycznych } \\
\text { w mieszaninach z PAO-4 }\end{array}$ \\
\cline { 2 - 5 } & wg ASTM D 2007-11 & wg PN-72/C-04025 & wg ASTM D 2007-11 & wg PN-72/C-04025 \\
\hline $\begin{array}{c}1+\text { PAO-4 } \\
33,0 \%(m / m)\end{array}$ & 83,2 & 82,4 & 83,5 & 83,0 \\
\hline $\begin{array}{c}2+\mathrm{PAO}-4 \\
32,4 \%(\mathrm{~m} / \mathrm{m})\end{array}$ & 76,0 & 72,8 & 76,1 & 72,5 \\
\hline
\end{tabular}

korelację wszystkich trzech metod oznaczania zawartości składników niearomatycznych, tj. sumy węglowodorów nasyconych i parafinowo-naftenowych. Otrzymano zawartości składników niearomatycznych zgodne z wartościami obliczonymi, podanymi w tablicy 3 .

Uzyskane wyniki badania mieszanin olejów bazowych grupy I z PAO-4 potwierdzają 100-proc. udział składnika PAO we frakcji węglowodorów nasyconych i pełną elucję tego składnika we frakcji składników niearomatycznych.
Wyniki oznaczania składu grupowego próbki oleju 2 + PAO-4 w przypadku zastosowania rozdziału wg Polskiej Normy oraz zawartości składników aromatycznych i niearomatycznych według załącznika A korelują ze sobą. Różnica między tymi wynikami wynosi 0,6\% ( $\mathrm{m} / \mathrm{m})$. Wynik oznaczania zawartości węglowodorów nasyconych według ASTM D 2007-11 jest wyższy od pozostałych, ale różnica wynosząca 3,6\% $(\mathrm{m} / \mathrm{m})$ jest mniejsza niż wartość odtwarzalności metody o najgorszej precyzji, tj. metody ASTM D $2007(R=4,0 \%(\mathrm{~m} / \mathrm{m}))$.

\section{Badania frakcji otrzymanych podczas przeprowadzania rozdziałów techniką chromatografii elucyjnej}

W przypadku gdy badanie olejów bazowych różnymi technikami chromatografii kolumnowej prowadzi do rozbieżnych wyników, konieczna może się okazać weryfikacja wiarygodności tych wyników innymi metodami analitycznymi.

W tym celu przeprowadzono badania mające ustalić, czy i w jakim zakresie metody chromatografii kolumnowej zapewniają właściwy rozdział składników aromatycznych od niearomatycznych. Można do tego wykorzystać technikę analizy spektralnej w podczerwieni (FT-IR) lub spektometrii UV-VIS, umożliwiające ocenę obecności struktur aromatycznych.

\section{Technika spektrometrii w podczerwieni (FT-IR)}

Widma w podczerwieni są charakterystyczne dla konkretnych związków chemicznych - przez to, że pasma na widmie odpowiadają drganiom grup funkcyjnych. Dana grupa funkcyjna (ugrupowanie kilku atomów połączonych ze sobą wiązaniami chemicznymi), występująca w różnych związkach, ma podobne wartości liczb falowych.

Analiza widma IR frakcji ,węglowodorów nasyconych” wydzielonej z oleju bazowego 2, według procedury opisanej w metodzie ASTM D 2007-11, wskazuje na obecność pasma o liczbie falowej około $1600 \mathrm{~cm}^{-1}$, czyli w zakresie typowym dla sygnałów wiązań aromatycznych (rysunek 5). Jednocześnie we frakcji parafinowo-naftenowej wydzielonej według PN-72/C-04025 brak jest na widmie piku świadczącego o obecności składników aromatycznych. Może to wskazywać na wyższą zdolność rozdzielczą stosowanej procedury chromatograficznej według Polskiej Normy.

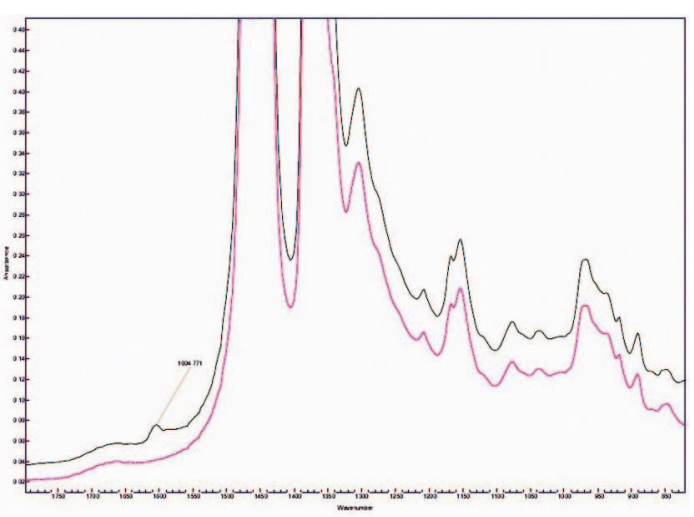

Rys. 5. Widma oleju bazowego - frakcja węglowodorów niearomatycznych z rozdziału wg ASTM D 2007-11 (zielona) oraz PN-72/C-04025 (różowa)

\section{Technika chromatografii gazowej}

Zastosowany układ chromatograficzny wykorzystano do wykonania obrazów chromatograficznych dla próbek frakcji o zakresie temperatury wrzenia olejów smarowych. W przypadku próbek z dodatkiem polialfaolefin (PAO) możliwe było stwierdzenie jakościowe ich obecności na podstawie zróżnicowanego przebiegu chromatogramu względem olejów mineralnych. Oleje mineralne pod względem chromatogramu charakteryzują się zwykle pojedynczym maksimum szerokiego piku chromatograficznego przypominającego kształtem krzywą Gaussa (rysunek 6).

W przypadku PAO na chromatogramie widoczne są zwykle trzy lub cztery maksima dla pików.

Obraz chromatograficzny frakcji niepolarnej mieszaniny oleju mineralnego i syntetycznego (rysunek 6) pozwala wyraźnie 
zauważyć obecność najlżejszych składników komponentu PAO (patrz również rysunek 4), natomiast pozostałe składniki są

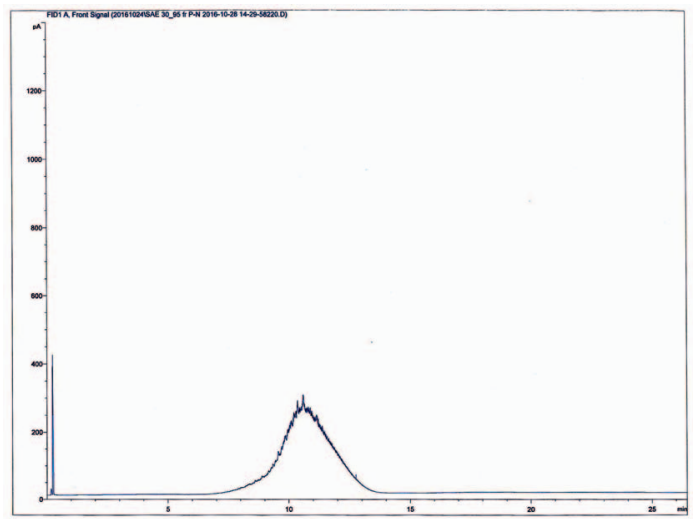

Rys. 6. Chromatogram frakcji parafinowo-naftenowej mieszaniny oleju bazowego 1 maskowane przez węglowodory nasycone eluowane $\mathrm{z}$ mineralnego składnika analizowanej mieszaniny.

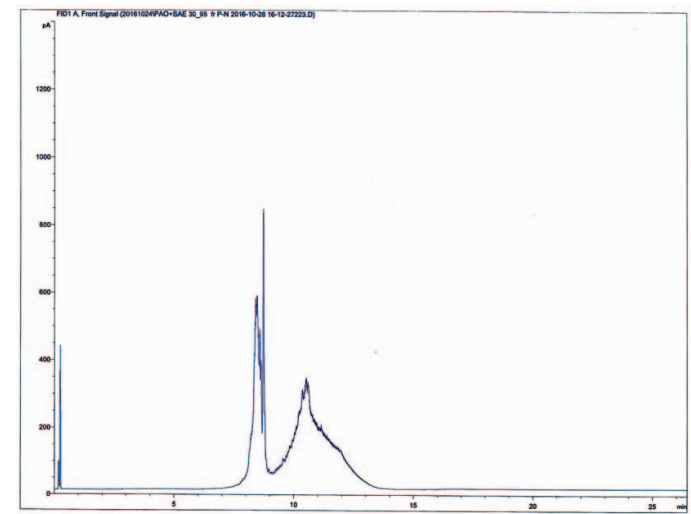

Rys. 7. Chromatogram frakcji parafinowo-naftenowej mieszaniny oleju bazowego 1 i PAO-4

\section{Podsumowanie}

Przeanalizowano wytypowane próbki olejów bazowych 2 oraz 1 i ich mieszanin z olejem bazowym IV grupy - polialfaolefiną PAO-4. Dokonano porównania otrzymanych trzema metodami wyników oznaczania składów grupowych. Stwierdzono, że duża zbieżność wyników występuje podczas analiz przeprowadzonych według PN-72/C-04025 oraz procedury opisanej w Załączniku A do działu 27 Not wyjaśniających do Nomenklatury Scalonej UE. Jednocześnie w każdym przypadku oznaczenie zawartości węglowodorów nasyconych przy zastosowaniu metody według ASTM D 2007-11 daje najwyższe wyniki.

Wykonane badania wydzielonych frakcji nasyconych wykazały obecność struktur aromatycznych w przypadku analizy próbek wydzielonych metodą według ASTM D 2007-11, stąd zawyżenie wyników w przypadku oznaczenia zawar- tości węglowodorów nasyconych i jednocześnie ich zaniżenie w przypadku oznaczenia zawartości węglowodorów aromatycznych.

Można stwierdzić, że stosunek ilości żelu krzemionkowego, na którym przebiega rozdział, do ilości rozdzielanego produktu nie jest wystarczający dla ustalenia równowagi dynamicznej sorpcji komponentów o różnej polarności i następuje mieszanie się rozdzielanych składników.

W ramach projektu przebadano techniką chromatografii gazowej wydzielone frakcje nasycone mieszaniny olejów bazowych z komponentem syntetycznym PAO-4. Zestawione wyniki oznaczania składu węglowodorowego mieszanin oraz analiza chromatograficzna potwierdziły, że komponent w całości jest eluowany wraz z węglowodorami nasyconymi i jego obecność nie wpływa na przebieg rozdziału.

Prosimy cytować jako: Nafta-Gaz 2018, nr 1, s. 67-74, DOI: 10.18668/NG.2018.01.08

Artykuł nadesłano do Redakcji 20.07.2017 r. Zatwierdzono do druku 22.11.2017 r.

Artykuł powstał na podstawie pracy statutowej pt.: Korelacja metod określania potencjału technologicznego surowców dla olejów bazowych $i$ smarowych - praca INiG - PIB na zlecenie MNiSW; nr zlecenia 73/TA/16, nr archiwalny: DK-4100-73/16.

\section{Literatura}

[1] Ashoori S., Sharifi M., Masoumi M., Salehi M.M.: The relationship between SARA fractions and crude oil stability. Egyptian Journal of Petroleum 2016, vol. 991, s. 255-266.

[2] Bartyzel A.: Syntetyczne oleje bazowe - oleje polialkenowe PIO. Nafta-Gaz 2013, nr 9, s. 690-694.

[3] ChunXiao Wang, Roger Firor: High-Temperature Simulated Distillation System Based on the 6890N GC. Agilent Application, 2005, http://www.agilent.com/cs/library/applications/59892727EN.pdf (dostęp: 11.07.2017).

[4] Kluk D.: Oznaczanie składu ropy naftowej z wykorzystaniem aplikacji SARA. Nafta-Gaz 2009, nr 3, s. 255-261.
[5] Krasodomski W.: Ocena możliwości wykorzystania techniki GC/MS do badania sktadu strukturalno-grupowego podstawowych olejów smarowych. Dokumentacja INiG, Kraków 2009, nr zlecenia: 0099/TA/2009, nr archiwalny: DK-4100-99/09.

[6] Kwinta M., Altkorn B.: Metodyka analitycznej charakterystyki rop naftowych dla potrzeb optymalizowania procesów technologicznych - 50 lat doświadczenia ITN. Nafta-Gaz 2009, nr 1, s. $14-20$.

[7] Mazur-Badura X., Krasodomski M.: Charakterystyka sktadu strukturalno-grupowego olejów napędowych i średnich frakcji naftowych z zastosowaniem GC/MS. Nafta-Gaz 2012, nr 7, s. 438-445. 
[8] Molina V.D., Uribe U.N., Murgich J.: Correlations between SARA fractions and physicochemical properties with ${ }^{1} H N M R$ spectra of vacuum residues from Colombian crude oils. Fuel 2010, vol. 89, no. 1, s. 185-192.

[9] Spaight J.G.: The Chemistry and Technology of Petroleum. Wyd. 4, CRC Taylor Francis, 2006.

\section{Akty prawne i normatywne}

[10] ASTM D 1319-15 Standard Test Method for Hydrocarbon Types in Liquid Petroleum Products by Fluorescent Indicator Adsorption.

[11] ASTM D 2007-2011 Standard Test Method for Characteristic Groups in Rubber Extender and Processing Oils and Other Petroleum-Derived Oils by the Clay-Gel Absorption Chromatographic Method.

[12] ASTM D 2549-02 (2007) Standard Test Method for Separation of Representative Aromatics and Nonaromatics Fractions of High-Boiling Oils by Elution Chromatography.

[13] ASTM D 4124-09 Standard Test Method for Separation of Asphalt into Four Fractions.

[14] Norma ASTM D 2425:04 Standard Test Method for Hydrocarbon Types in Middle Distillates by Mass Spectroscopy.

[15] Norma ASTM D 2887 Standard Test Method for Boiling Range Distribution of Petroleum Fractions by Gas Chromatography.
[16] PN-72/C-04025 Oznaczanie składu grupowego węglowodorów metoda chromatografii elucyjnej.

[17] PN-EN 12916-2016-03 Przetwory naftowe-Oznaczanie grup węglowodorów aromatycznych $w$ średnich destylatach $-\mathrm{Me}$ toda wysokosprawnej chromatografii cieczowej z detektorem współczynnika załamania światta.

[18] PN-EN 15553-2009 Przetwory naftowe i materiaty podobne - Oznaczanie zawartości grup węglowodorów - Metoda adsorpcyjna ze wskaźnikiem fluoroscencyjnym.

[19] Załącznik A do działu 27 Not wyjaśniających do Nomenklatury Scalonej Unii Europejskiej, pt. Metody oznaczania zawartości aromatycznych skladników $w$ produktach o końcowej temperaturze destylacji przekraczajacej $315^{\circ} \mathrm{C}$.

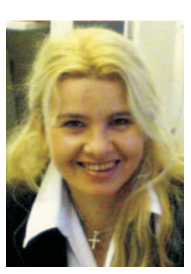

Mgr inż. Agnieszka WIECZOREK

Specjalista badawczo-techniczny w Zakładzie Analiz Naftowych, kierownik Pracowni Analiz Instrumentalnych.

Instytut Nafty i Gazu - Państwowy Instytut Badawczy ul. Lubicz 25 A, 31-503 Kraków

E-mail: agnieszka.wieczorek@inig.pl

\section{OFERTA}

\section{ZAKŁAD ANALIZ NAFTOWYCH}

Zakres działania:

- $\quad$ kompleksowa analiza rop naftowych;

- badanie składu chemicznego i ocena jakości produktów naftowych, biokomponentów, biopaliw, paliw alternatywnych

- $\quad$ ocena potencjalnej kancerogenności produktów naftowych, w tym test DAB-10;

- oznaczanie metali ciężkich w produktach naftowych świeżych i zużytych oraz w odpadach;

- $\quad$ identyfikacja substancji pochodzących z degradacji produktów naftowych;

- usługi: monitorowania jakości paliw ciekłych i biopaliw, monitorowania jakości LPG, monitorowania stopnia zużycia olejów silnikowych w pojazdach;

- opracowywanie nowych metod analitycznych dla produktów naftowych i pokrewnych: świeżych, w eksploatacji i zużytych;

- $\quad$ identyfikacja i oznaczanie toksycznych związków emitowanych z silników wysokoprężnych (WWA w cząstkach stałych PM);

- $\quad$ usługi eksperckie i rzeczoznawcze w zakresie: orzecznictwa o jakości paliw silnikowych, analityki produktów naftowych, problemów związanych z eksploatacją produktów naftowych i produktów pokrewnych;

- $\quad$ badania i doradztwo w zakresie klasyfikacji surowców i produktów naftowych w odniesieniu do Nomenklatury Scalonej (CN);

- $\quad$ opracowanie kart charakterystyki substancji niebezpiecznych dla branży naftowej i branż pokrewnych;

- badania odporności rop naftowych i paliw na przechowywanie w kawernach solnych.

Kierownik: dr inż. Beata Altkorn

Adres: ul. Łukasiewicza 1, 31-429 Kraków

Telefon: 126177500

Faks: 126177680,126177522

E-mail: beata.altkorn@inig.pl 